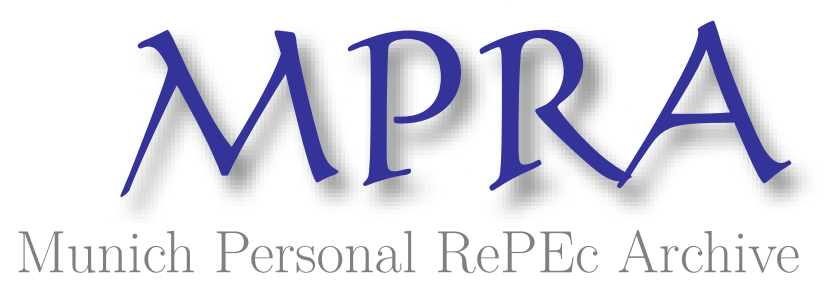

\title{
Demand for Money in the Selected OECD Countries: A Time Series Panel Data Approach and Structural Breaks
}

Kumar, Saten and Chowdhury, Mamta and Rao, B.

Bhaskara

Auckland University of Technology

10 April 2010

Online at https://mpra.ub.uni-muenchen.de/22204/

MPRA Paper No. 22204, posted 19 Apr 2010 17:58 UTC 
Demand for Money in the Selected OECD Countries:

\title{
A Time Series Panel Data Approach and Structural Breaks
}

\author{
Saten Kumar \\ kumar_saten@yahoo.com \\ Auckland University of Technology, Auckland (New Zealand) \\ Mamta Chowdhury \\ mamta.chowdhury@uws.edu.au \\ University of Western Sydney, Sydney (Australia) \\ B. Bhaskara Rao ${ }^{1}$ \\ raob123@bigpond.com \\ University of Western Sydney, Sydney (Australia)
}

\begin{abstract}
Time series panel data estimation methods are used to estimate cointegrating equations for the demand for money (M1) for a panel of 11 OECD countries. The effects of financial reforms are analysed with structural break tests and estimates for alternative sub-samples. Our results in the post-reforms sub-samples show that the income elasticity of the demand for money has decreased and response to interest rate changes has increased.
\end{abstract}

Keywords: Demand for money, Pedroni FMOLS, financial reforms

JEL: C33, E41

${ }^{1}$ Corresponding author. 


\section{Introduction}

Estimates of the demand for money and its stability have become controversial after 1970s due to the instability caused by financial reforms. Reforms have improved efficiency of the financial markets. A variety of money substitutes for transactions - eg., credit and debit cards and electronic money transfers etc.,- is created. Reforms have enhanced competition and improved international capital mobility. It is now a stylized fact that the demand for various monetary aggregates has become unstable in the advanced countries following the reforms of the 1970s. Furthermore, developments in the estimation methods due to the challenges posed by the time series methods have raised doubts on the validity of the earlier estimates. Consequently, central banks in many advanced countries have switched from using money supply to the rate of interest as their instrument of monetary policy since it is not possible to forecast accurately the target with an unstable and unreliable estimate of the demand for money. ${ }^{2}$ This is also consistent with Poole's (1970) analysis. According to him money supply should be targeted when the demand for money is stable and the rate of interest when this relationship is unstable. Use of an incorrect instrument will only accentuate instability. ${ }^{3}$

Although stability of the demand for money in the advanced countries has been investigated by many earlier studies, there do not seem to be many recent studies with the exception of Nielson (2004), Friedman and Kuttner (1992), Ball (2001) and Rao and Kumar (2009a). ${ }^{4}$ While Friedman and Kuttner and Ball found that the demand for money

\footnotetext{
${ }^{2}$ However, some studies support the Taylor rule based interest rate targeting; see Orden and Fisher (1993) for Australia, McPhail (1991) and Haug (1999) for Canada, Maki and Kitasaka (2006) and Nagayasu (2003) for Japan, Papadopoulos and Zis (1997) for Greece, Vega (1995; 1998) for Spain, Caporale and Gil-Alana (2005) and Oxley (1983) for UK and Breuer and Lippert (1996) for USA.

${ }^{3}$ Following the advanced countries, central banks in many developing countries have also switched to targeting the rate of interest without any credible evidence that their money demand functions have become unstable. This shift has been questioned by Bahmani-Oskooee and Rehman (2005), Sumner (2009), Rao and Kumar (2009b), Bahmani-Oskooee and Gelan (2009) and Yu and Gan (2009). These authors have found no instability in the demand for money functions using alternative estimation methods and data mainly from the Asian countries.

${ }^{4}$ Nielson (2004) examined the UK money demand (M2, M3 and M4) for the period 1873-2001 and stability results suggest that the long run demand for money is stable. According to Friedman and Kuttner (1992), the US demand for M1 is cointegrated for the period 1960-1979, but becomes unstable if sample is extended from 1980. Ball's (2001) study for the USA, notes that stability tests did not show breaks in the demand for M1 up to 1987, but becomes unstable when the samples are extended up to 1996.
} 
is unstable in the post reforms samples, Rao and Kumar found that the US demand for money has now become stable. Nielson found similarly the demand for money in the UK is stable in the post reforms samples. As a plausible reason it may be suggested that the improved stability may be due to the wearing off of the major effects of reforms by now. Given these findings the contribution of this paper is twofold. First, we shall use panel time series methods to estimate the demand for narrow money for 11 advanced OECD countries and second we test the stability of this function with the structural breaks test of Westerlund (2006). Since these OECD countries have implemented a number of financial reforms during much of the 1970s and 1980s, the effectiveness of such reforms may be observed as structural breaks in the cointegrating equations. If financial reforms were effective there should be some enhanced economies of scale and therefore it is expected that the income elasticity should show a decline and the response to changes in the rate of interest should increase. If the demand for money has not become stable by now there should not be well defined cointegrating equations for the whole sample period and the post reforms subsample periods. With these objectives in mind the outline of this paper can be stated as follows. Section 2 briefly reviews a few relevant empirical works. In Section 3 empirical results for panel unit root and cointegration tests and estimates of the cointegrating equations are presented. Test results for structural breaks are in Section 4 and Section 5 concludes.

\section{Review of Panel Data Studies}

Although many recent empirical studies on the demand for money have used country specific data and time series methods, a number of studies have also used panel data and panel estimation methods; Mark and Sul (2003), Valadkhani and Alauddin (2003), Harb (2004), Garcia-Hiernaux and Cerno (2006), Lee and Chang (2006), Fidrmuc (2009), Dreger et al. (2007), Elbadawi and Schmidt-Hebbel (2007), Carrera (2008), Valadkhani (2008), Hamori and Hamori (2008), Hamori (2008), Rao and Kumar (2009b), Rao et al. (2009) and Setzer and Wolff (2009). Essentially these studies, both on the

\footnotetext{
${ }^{5}$ The cross section and time series studies are well surveyed earlier by Sriram (1999 and 2001). Recently, Duca and VanHoose (2004) provided a useful survey of the theoretical and empirical literature on the demand for money.
} 
developed and developing countries, have estimated one or another of the following specifications for the demand for money.

$$
\begin{aligned}
& \ln M_{i t}=\alpha_{1 i}+\alpha_{2 i} \ln Y_{i t}+\alpha_{3 i} r_{i t}+\varepsilon_{i t} \\
& \ln M_{i t}=\alpha_{1 i}+\alpha_{2 i} \ln Y_{i t}+\alpha_{3 i} r_{i t}+\alpha_{4 i} \ln E_{i t}+\varepsilon_{i t} \\
& \ln M_{i t}=\alpha_{1 i}+\alpha_{2 i} \ln Y_{i t}+\alpha_{3 i} r_{i t}+\alpha_{4 i} \ln E_{i t}+\alpha_{5 i} \pi_{i t}+\varepsilon_{i t}
\end{aligned}
$$

where $M$ is real money stock, $Y$ is real income, $r$ is nominal rate of interest, $E$ is real effective exchange rate, $\pi$ is inflation rate, $i$ and $t$ are country and time subscripts and $\varepsilon_{i t} \square N(0, \sigma)$ for all $i$ and $t$.

Table 1 below summarises the estimated income elasticities and their main findings of some of these empirical works. While the majority of these panel data studies found that the income elasticity is near unity, estimates by Garcia-Hiernaux and Cerno (2006) are low at about 0.2 and that by Dreger et al. (2007) is high exceeding 1.7. We shall treat these two studies as exceptional to the findings of the majority of the panel data studies. As stated before, it is to be expected that in the post reforms samples the income elasticity for the OECD countries is expected to be lower because of the improvements in the efficiency of the financial markets.

Before we present our estimates and examine the stability of the demand for money it would be useful to briefly state a few details of the works in Table 1 . The samples of Mark and Sul (2003), Dreger et al. (2007), Hamori and Hamori (2008), Fidrmuc (2009) and Setzer and Wolff (2009) are for varying number of the OECD countries. Mark and Sul (2003) have applied panel DOLS method to estimate the demand for M1 using a panel of 19 OECD countries from 1957 to 1996 . When a time trend was included, the estimated panel income elasticity was 1.08 with an interest rate semielasticity of -0.02. Fidrmuc (2009) have used Pedroni's panel FMOLS and Kao's (1999) panel DOLS techniques to examine M2 demand for six Central and Eastern European countries (CEEC) viz., Czech Republic, Hungary, Poland, Romania, Slovakia, and Slovenia over the period 1994-2003. They found that money demand depends significantly on the Euro area interest rates and the exchange rate against the Euro. Dreger et al. (2007) have used quarterly data for the period 1995(Q1)-2004(Q2) and three panel cointegration techniques (Pedroni, 2000; Mark and Sul, 2003 and Breitung, 2006) to 


\begin{tabular}{|c|c|c|c|c|c|c|}
\hline \multicolumn{7}{|c|}{$\begin{array}{c}\text { Table 1 } \\
\text { Panel Data Studies on Money Demand and their Findings }\end{array}$} \\
\hline Author & $\begin{array}{l}\text { Period; } \\
\text { Monetary } \\
\text { Aggregate }\end{array}$ & Country & $\begin{array}{l}\text { Specification; } \\
\text { Methodology }\end{array}$ & $\begin{array}{l}\text { Panel } \\
\text { Income } \\
\text { Elasticity }\end{array}$ & $\begin{array}{l}\text { Panel } \\
\text { Interest Rate } \\
\text { Elasticity }\end{array}$ & Main Findings \\
\hline $\begin{array}{l}\text { Garcia-Hiernaux } \\
\text { and Cerno (2006) }\end{array}$ & $\begin{array}{l}\text { 1988-1998; } \\
\text { M0 }\end{array}$ & $\begin{array}{l}27 \\
\text { developed } \\
\text { and } \\
\text { developing } \\
\text { countries }\end{array}$ & Eq 1; GMM & $\begin{array}{l}0.180 \\
(6.80)^{*} \\
0.200 \\
(2.00)^{*}\end{array}$ & $\begin{array}{l}-0.004 \\
(2.90)^{*} \\
-0.005 \\
(1.70)^{* *}\end{array}$ & $\begin{array}{l}\text { The income } \\
\text { elasticity is in } \\
\text { contrast to Cagan's } \\
\text { (1956) findings. }\end{array}$ \\
\hline $\begin{array}{l}\text { Dreger et al. } \\
(2007)\end{array}$ & $\begin{array}{l}\text { 1995(q1)- } \\
\text { 2004(q2); } \\
\text { M2 }\end{array}$ & $\begin{array}{l}10 \mathrm{EU} \\
\text { Countries }\end{array}$ & $\begin{array}{l}\text { Eq 2; Pedroni } \\
\text { Mark \& Sul } \\
\text { Breitung }\end{array}$ & $\begin{array}{l}1.730 \\
(21.63)^{*} \\
1.940 \\
(14.92)^{*} \\
1.780 \\
(17.80)^{*}\end{array}$ & $\begin{array}{l}-0.090 \\
(4.50)^{*} \\
-0.070 \\
(2.33)^{*} \\
-0.060 \\
(3.00)^{*}\end{array}$ & $\begin{array}{l}\text { Introduction of } \\
\text { Euro in new EU } \\
\text { member states may } \\
\text { have created } \\
\text { instability in the } \\
\text { Euro area money } \\
\text { demand. }\end{array}$ \\
\hline $\begin{array}{l}\text { Mark and Sul } \\
(2003)\end{array}$ & $\begin{array}{l}\text { 1957-1996: } \\
\text { M1 }\end{array}$ & $\begin{array}{l}19 \text { OECD } \\
\text { Countries }\end{array}$ & Eq 1; DOLS & $\begin{array}{l}1.079 \\
(4.09)^{*}\end{array}$ & $\begin{array}{l}-0.022 \\
(3.67)^{*}\end{array}$ & $\begin{array}{l}\text { Without time } \\
\text { trend, income } \\
\text { elasticity is } 0.860 \text {. }\end{array}$ \\
\hline Harb (2004) & $\begin{array}{l}\text { 1979-2000; } \\
\text { M1 \& M2 }\end{array}$ & $\begin{array}{l}6 \text { GCC } \\
\text { Countries }\end{array}$ & Eq 2; Pedroni & $\begin{array}{l}0.780 \\
(11.48)^{*} \\
0.420 \\
(5.52)^{*}\end{array}$ & $\begin{array}{l}-0.050 \\
(2.36)^{*} \\
0.010 \\
(0.33)\end{array}$ & $\begin{array}{l}\text { Real M1yields } \\
\text { more robust } \\
\text { relation than real } \\
\text { M2. }\end{array}$ \\
\hline Carrera (2008) & $\begin{array}{l}\text { 1948-2003; } \\
\text { M1 }\end{array}$ & $\begin{array}{l}15 \text { Latin } \\
\text { American } \\
\text { Countries }\end{array}$ & Eq 1; Pedroni & $\begin{array}{l}0.940 \\
(50.20)^{*}\end{array}$ & $\begin{array}{l}-0.008 \\
(11.43)^{*}\end{array}$ & $\begin{array}{l}\text { The country } \\
\text { specific income } \\
\text { elasticity is around } \\
\text { unity in many } \\
\text { Latin American } \\
\text { countries. }\end{array}$ \\
\hline $\begin{array}{l}\text { Valadkhani and } \\
\text { Alauddin (2003) }\end{array}$ & $\begin{array}{l}\text { 1979-1999; } \\
\text { M2 }\end{array}$ & $\begin{array}{l}8 \text { Asian } \\
\text { Countries }\end{array}$ & Eq 3; SUR & $\mathrm{n} / \mathrm{a}$ & $\mathrm{n} / \mathrm{a}$ & $\begin{array}{l}\text { The country } \\
\text { specific income } \\
\text { elasticities range } \\
\text { between } 0.3 \text { to } 1.4 \text {. }\end{array}$ \\
\hline $\begin{array}{l}\text { Rao and Kumar } \\
(2009 b)\end{array}$ & $\begin{array}{l}\text { 1970-2005; } \\
\text { M1 }\end{array}$ & $\begin{array}{l}14 \text { Asian } \\
\text { Countries }\end{array}$ & $\begin{array}{l}\text { Eq 1; Pedroni } \\
\text { Mark \& Sul } \\
\text { Breitung }\end{array}$ & $\begin{array}{l}1.140 \\
(20.84)^{*} \\
0.990 \\
(32.00)^{*} \\
0.960 \\
(60.19)^{*}\end{array}$ & $\begin{array}{l}-0.020 \\
(5.60)^{*} \\
-0.010 \\
(2.75)^{*} \\
-0.010 \\
(5.24)^{*}\end{array}$ & $\begin{array}{l}\text { Demand for } \mathrm{M} 1 \text { is } \\
\text { stable in these } \\
\text { countries. }\end{array}$ \\
\hline Rao et al. (2009) & $\begin{array}{l}\text { 1970-2007; } \\
\text { M1 }\end{array}$ & $\begin{array}{l}11 \text { Asian } \\
\text { Countries }\end{array}$ & Eq 3; SGMM & $\begin{array}{l}1.190 \\
{[0.00]^{*}} \\
1.160 \\
{[0.00]^{*}}\end{array}$ & $\begin{array}{l}-0.543 \\
{[0.00]^{*}} \\
-0.512 \\
{[0.00]^{*}}\end{array}$ & $\begin{array}{l}\text { There exists well } \\
\text { defined } \\
\text { M1demand with } \\
\text { no structural } \\
\text { breaks. }\end{array}$ \\
\hline $\begin{array}{l}\text { Setzer and Wolff } \\
(2009)\end{array}$ & $\begin{array}{l}\text { 2003(q1)- } \\
2008(q 3) \\
\text { M3 }\end{array}$ & Euro Area & Eq 1; DOLS & $\begin{array}{l}1.670 \\
(5.90)^{*}\end{array}$ & $\begin{array}{l}-0.090 \\
(3.12)^{*}\end{array}$ & $\begin{array}{l}\text { Strong money } \\
\text { growth has not } \\
\text { altered demand for } \\
\text { M3. }\end{array}$ \\
\hline Hamori (2008) & $\begin{array}{l}\text { 1980-2005 } \\
\text { M1 \& M2 }\end{array}$ & $\begin{array}{l}35 \text { Sub- } \\
\text { Saharan } \\
\text { African } \\
\text { countries }\end{array}$ & Eq 1; Pedroni & $\begin{array}{l}0.86 \\
(32.79)^{*} \\
1.00 \\
(40.37)^{*}\end{array}$ & $\begin{array}{l}-0.020 \\
(6.63)^{*} \\
-0.010 \\
(2.76)^{*} \\
\end{array}$ & $\begin{array}{l}\text { Money supply is a } \\
\text { reliable monetary } \\
\text { policy instrument. }\end{array}$ \\
\hline \multicolumn{7}{|c|}{$\begin{array}{l}\text { Notes: t-statistics are in the parenthesis and * denotes significance at } 5 \% \text { level. In Rao et al. (2009) p-values are in the } \\
\text { square brackets. Valadkhani and Alauddin (2003) did not report income elasticity. DOLS, GMM, SGMM, SUR mean, } \\
\text { respectively, Dynamic Ordinary Least Squares, Generalized Method of Moments, Systems Generalized Method of } \\
\text { Moments and Seemingly Unrelated Regressions. In all cases, semi-interest rate elasticity is provided, except Rao et al. } \\
(2009) \text {. }\end{array}$} \\
\hline
\end{tabular}


estimate broad money (M3) demand for ten EU countries. ${ }^{6}$ The estimate of the panel income elasticity was between 1.73 and 1.94, while the interest rate elasticity is negative and significant. Dreger et al. argued that sudden introduction of the Euro in all new EU member states may have introduced problems for the stability of the Euro area money demand function. Hamori and Hamori (2008) have estimated the money demand (M1, M2 and M3) using the Pedroni FMOLS method and data from January 1999 through March 2006, covering the $11 \mathrm{EU}$ countries. ${ }^{7}$ They find that there is a long run relationship between monetary aggregates and its determinants. Setzer and Wolff (2009) have estimated demand for M3 for Euro area using the panel DOLS technique. They found that the income elasticity for M3 was around 1.67 for the sample 2003 to 2008, while for the sample starting from 2001, this was 1.20 . Their findings imply that income elasticity has increased which is contrary to expectation because financial reforms will allow improved scale economies thereby reducing the income elasticity.

Utilizing the panel data techniques (Pedroni, 2004; Mark and Sul, 2003 and Breitung, 2006), Rao and Kumar (2009b) have estimated the demand for M1 for a panel of 14 Asian countries for the period 1970-2005. In all cases, the panel income elasticities were around unity. Their results showed that there is a well defined demand for M1 in these countries. Similar conclusions are made by Rao et al. (2009) for 11 Asian countries using panel SGMM technique and data from 1970-2007.

Combining observations across Latin-American countries for the period 19482003, Carrera (2008) has found, with the Pedroni panel FMOLS method, that the income elasticity is 0.94 and the semi-interest elasticity as -0.008 . Hamori (2008) has used data over 1980-2005 and the Pedroni panel FMOLS method to estimate the demand for M1 and M2 for 35 Sub-Saharan African countries. The income elasticities are found to be 0.9 and 1 for M1 and M2, respectively. The semi-interest rate elasticity is also significant with expected negative sign.

However, in all these studies there are no formal tests for structural breaks in the relationship, except in Rao et al., (2009) where they have used Mancini-Griffoli and Pauwels (2006) test for structural breaks for the estimates with SGMM. Given that a number of major financial reforms were implemented by many OECD countries to

\footnotetext{
${ }^{6}$ These EU countries are Cyprus, Czech Republic, Estonia, Hungary, Latvia, Lithunia, Malta, Poland, Slovak Republic and Slovenia.

${ }^{7}$ These countries are Austria, Belgium, Finland, France, Germany, Ireland, Italy, Luxembourg, Netherlands, Portugal, and Spain.
} 
enhance the efficiency of the financial sector, it is likely that structural changes might have taken place in the demand for money. In this paper we shall examine this aspect of the demand for money with a test procedure for structural breaks in the time series panel data estimates of Westerlund (2006).

\section{Unit roots and Cointegration}

We shall use quarterly data for 11 OECD countries for the period 1975Q1-2008Q4. These countries are Australia, Canada, Japan, Korea, Italy, Mexico, Norway, Spain, Sweden, Switzerland and USA. These countries and the data period are selected because there are no gaps in the data on the variables and therefore our data set is balanced. ${ }^{8}$ Definitions of the variables and sources of data are in the appendix. The dependent variable is the real narrow money M1.

We first tested for the order of the variables viz., $\ln M, \ln Y, r, \ln E$ and $\pi$ using the panel unit root tests of Levin, Lin and Chu (2002, LLC), Breitung (2000), Im, Pesaran and Shin (2003, IPS), ADF Fisher $\chi^{2}$ (ADF), PP Fisher $\chi^{2}$ (PP), and Hadri (2000). The panel unit root test results are in Table 2 . These tests gave fairly unambiguous results for $\ln M$ and $\ln E$. The LLC, IPS, ADF, PP and Breitung tests in which the null is that the variable is non-stationary is not rejected at the 5\% level. In the Hadri test with the null that the variable is stationary is also rejected for these 2 variables at the $5 \%$ level. For $\ln Y$ and $r$, all the tests show that they are non-stationary variables at the 5\% level, except in the LLC test at the $1 \%$ level. For $\pi$ all the tests show that it is stationary, except the Hadri test. With the exception of the Hadri test, all other tests show that the first differences of all the variables are stationary. Therefore, it is reasonable to infer that these variables are $I(1)$ in levels, except $\pi$. Since the Hadri test provides support that $\pi$ is non-stationary, we proceed to test and estimate the cointegrating vectors for the specifications in equations (1) and (3).

The results for cointegration tests for equations (1) and (3) are in Table 3. The majority of the reported 7 tests show that there is cointegration between the variables

\footnotetext{
${ }^{8}$ The IFS and the World Bank database did not publish data on M1 after 1998 for some major OECD countries (for example France, Germany, Greece, Ireland, Netherlands and the UK) and this has constrained our selection of countries. Furthermore, for compatibility we have used the IFS and World Bank sources for data.
} 


\begin{tabular}{|l|c|c|c|c|c|c|}
\hline \multicolumn{7}{|c|}{ Panel Unit Root Tests 1975Q1-2008Q4 } \\
\hline Series & LLC & Breitung & IPS & ADF & PP & Hadri \\
\hline $\ln M$ & 0.375 & 0.488 & 1.672 & 9.247 & 8.253 & 8.781 \\
& $(0.646)$ & $(0.687)$ & $(0.953)$ & $(0.980)$ & $(0.990)$ & $(0.000)^{*}$ \\
\hline $\ln Y$ & -2.379 & 3.320 & -0.579 & 29.536 & 19.745 & 10.371 \\
& $(0.009)^{*}$ & $(0.999)$ & $(0.281)$ & $(0.078)^{* *}$ & $(0.474)$ & $(0.000)^{*}$ \\
\hline$r$ & -2.556 & -0.414 & -0.187 & 24.500 & 10.552 & 10.303 \\
& $(0.005)^{*}$ & $(0.340)$ & $(0.426)$ & $(0.221)$ & $(0.957)$ & $(0.000)^{*}$ \\
\hline $\ln E$ & 2.408 & 2.404 & 3.664 & 9.780 & 6.945 & 8.281 \\
& $(0.992)$ & $(0.992)$ & $(1.000)$ & $(0.972)$ & $(0.997)$ & $(0.000)^{*}$ \\
\hline$\pi$ & -4.843 & -4.092 & -5.055 & 62.395 & 50.775 & 6.584 \\
& $(0.000)^{*}$ & $(0.000)^{*}$ & $(0.000)^{*}$ & $(0.000)^{*}$ & $(0.000)^{*}$ & $(0.000)^{*}$ \\
\hline$\Delta \ln M$ & -17.190 & -8.061 & -14.704 & 195.964 & 192.819 & 2.800 \\
& $(0.000)^{*}$ & $(0.000)^{*}$ & $(0.000)^{*}$ & $(0.000)^{*}$ & $(0.000)^{*}$ & $(0.003)^{*}$ \\
\hline$\Delta \ln Y$ & -14.720 & -7.439 & -13.649 & 178.701 & 183.202 & 3.390 \\
& $(0.000)^{*}$ & $(0.000)^{*}$ & $(0.000)^{*}$ & $(0.000)^{*}$ & $(0.000)^{*}$ & $(0.000)^{*}$ \\
\hline$\Delta r$ & -18.003 & -12.419 & -15.339 & 206.323 & 296.527 & 4.126 \\
& $(0.000)^{*}$ & $(0.000)^{*}$ & $(0.000)^{*}$ & $(0.000)^{*}$ & $(0.000)^{*}$ & $(0.000)^{*}$ \\
\hline$\Delta \ln E$ & -9.037 & -1.324 & -8.133 & 104.134 & 98.690 & 5.041 \\
& $(0.000)^{*}$ & $(0.093)^{* *}$ & $(0.000)^{*}$ & $(0.000)^{*}$ & $(0.000)^{*}$ & $(0.000)^{*}$ \\
\hline$\Delta \pi$ & -15.164 & -9.512 & -15.132 & 218.088 & 761.325 & 8.069 \\
& $(0.000)^{*}$ & $(0.000)^{*}$ & $(0.000)^{*}$ & $(0.000)^{*}$ & $(0.000)^{*}$ & $(0.000)^{*}$ \\
\hline Notes: Probability values are reported in the parentheses. *and ** denotes the rejection of the null at the \\
$5 \%$ and 10\% levels, respectively. Baltagi (2005) and Pesaran and Breitung (2005) provide detailed \\
discussion of these tests.
\end{tabular}

at the 5\% level. Only the panel $v$ and panel $\sigma$ test statistics in (1) and panel $\sigma$ and panel $\rho \rho$ test statistics in (3) are insignificant at the $10 \%$ level. It is well known that the two $A D F$ tests have more power against the null and they reject the null of no cointegration at the 5\% level. Therefore, it can be concluded that the variables in (1) and (3) are cointegrated and a long run demand for money function exists for the group as a whole and the members of the panel.

\begin{tabular}{|c|c|c|}
\hline \multicolumn{3}{|c|}{ Table 3 } \\
Panel Cointegration Tests 1975Q1-2008Q4 \\
\hline Test Statistic & \multicolumn{2}{|c|}{ Random Effects } \\
\hline & Eq. 1 & Eq. 3 \\
\hline Panel $v$ - statistic & -0.777 & $-1.782^{* *}$ \\
\hline Panel $\sigma$ - statistic & -1.196 & 0.234 \\
\hline Panel $\rho \rho$ - statistic & $-1.696^{* *}$ & -0.488 \\
\hline Panel ADF-statistic & $2.865^{*}$ & $3.337^{*}$ \\
\hline Group $\sigma$ - statistic & $-6.483^{*}$ & $-2.344^{*}$ \\
\hline Group $\rho \rho$ - statistic & $-2.876^{*}$ & $-1.934^{* *}$ \\
\hline Group ADF- statistic & $3.265^{*}$ & $3.726^{*}$ \\
\hline $\begin{array}{l}\text { Notes: The test statistics are distributed as } N(0,1) . \\
\text { significance, respectively, at } 5 \% \text { and } 10 \% \text { levels. }\end{array}$ \\
\hline
\end{tabular}


Table 4 provides the estimated panel group cointegrating parameters for the random effects models with the Pedroni FMOLS method. ${ }^{9}$ Estimates of income elasticity and semi-interest rate elasticity in equations (1) and (3) differ only marginally and both are significant at the 5\% level. The income elasticities are 0.870 and 0.825 , respectively, and the coefficient of the rate of interest has the expected negative sign but differ because additional variables are used, besides the rate of interest, in equation (3) to proxy the cost of holding money. In equation (3) the coefficient of exchange rate is significant at the 5\% level but the rate of inflation is insignificant. On the basis of the above estimates we may conclude that for the whole sample period estimates of income elasticity are slightly lower than unity and money demand is responsive to changes in the cost of holding money.

\begin{tabular}{|l|c|c|}
\hline \multicolumn{3}{|c|}{ Table 4 } \\
\hline \multicolumn{2}{|c|}{ Estimates of the Cointegration Coefficients 1975Q1-2008Q4 } \\
\hline & Eq 1. & Eq 3. \\
\hline & \multicolumn{2}{|c|}{ Random Effects Model } \\
\hline $\ln Y$ & 0.870 & 0.825 \\
& $(40.20)^{*}$ & $(30.39)^{*}$ \\
\hline$r$ & -0.054 & -0.012 \\
& $(13.18)^{*}$ & $(11.42)^{*}$ \\
\hline $\ln E$ & & -0.030 \\
& & $(2.98)^{*}$ \\
\hline$\pi$ & & -0.808 \\
& & $(0.43)$ \\
\hline Notes: t-ratios are in the parentheses and * indicates significance \\
at the 5\% level.
\end{tabular}

\section{Impact of Financial Reforms}

We shall examine the effects of the financial reforms on the demand for money in our sample of the 11 OECD countries. Financial reforms have been implemented in the OECD countries from late 1960s to early 1970s and it is difficult to argue that all these countries have undergone reforms process at the same time. Indeed it is difficult to select a common break date for all the countries in our panel. Therefore we utilise the recently

\footnotetext{
${ }^{9}$ Estimates of the individual country cointegrating parameters are not reported to conserve space but are available from authors upon request.
} 
developed Westerlund (2006) structural break tests to investigate the break dates in our sample. Table 5 reports the single endogenous break results in the intercepts and trends. ${ }^{10}$ Explicitly it can be observed that these countries have undergone structural changes which we assume is due to financial reforms at different, but close time periods. USA is the dominant OECD country with a break date at 1986Q1. There are seven countries (Australia, Japan, Mexico, Norway, Spain, Sweden, and USA) with early break dates somewhat during 1980s and close to the break date for the USA. However, four countries

\begin{tabular}{|l|l|l|l|l|l|l|l|l|l|l|l|}
\hline \multicolumn{1}{|c|}{ Table 5 } \\
\hline Country & $(1)$ & $(2)$ & $(3)$ & $(4)$ & $(5)$ & $(6)$ & $(7)$ & $(8)$ & $(9)$ & $(10)$ & $(11)$ \\
\hline Break & 1987 & 1994 & 1983 & 1994 & 1991 & 1983 & 1987 & 1984 & 1988 & 1996 & 1986 \\
Date & Q3 & Q2 & Q2 & Q2 & Q4 & Q1 & Q1 & Q3 & Q1 & Q3 & Q1 \\
\hline
\end{tabular}

Note: Single endogenous break dates are reported. Countries are numbered from (1) to (11) for example (1) Australia, (2) Canada, (3) Japan, (4) Korea, (5) Italy, (6) Mexico, (7) Norway, (8) Spain, (9) Sweden, (10) Switzerland and (12) USA.

(Canada, Korea, Italy and Switzerland) have delayed break dates during 1990s which may be due to a late start of financial reforms. Although it is difficult to develop sub-samples based on different break dates, we adopt the following pragmatic approach to analyse the impact of financial reforms. First, we use the USA break date of 1986Q1 because it is the dominant country in our sample. In this case, our sub-sample periods are 1975Q1-1985Q4 and 1986Q1-2008Q4. Second, we group the countries into two types i.e., countries that had an early break date and those that had a late break date. It is worth noting that USA is one of the seven countries that have an early break date, and therefore it would be reasonable to construct the sub-samples for these countries as 1975Q1-1985Q4 and 1986Q1-2008Q4. Conversely, Canada and Korea are amongst the four countries that had a common late break date i.e., 1994Q2 . To this end, we select the sub-samples as 1975Q1-1994Q1 and 1994Q2-2008Q4 for these four countries.

Before further discussion, it would be useful to take an overview of what is expected from these sub-sample estimates. If financial reforms have been effective, it is to

\footnotetext{
${ }^{10}$ Although it is also possible to test for multiple breaks we decided to test for one dominant break because our data covers only a shorter period of about 30 years and after some immediate and initial effects of reforms might have taken place i.e., from 1975 due to gaps in data. Multiple breaks may also give conflicting break dates and increase the number of sub-samples. Therefore, testing for a single dominant break is a pragmatic option.
} 
be expected that there will be evidence for some economies of scale in the use of $M 1$ and also the response to the rate of interest will improve because of more market based interest rate policies. Consequently, it is to be expected in the second set of sub-samples income elasticity will show a decline and the absolute value of the interest rate coefficient will increase. The instability in the demand for money may also be observed if reforms have generated considerable quantity of near monies. This should be reflected in the second set of sub-samples as lack of a well defined long run relationship between money and its determinants i.e., cointegration tests might show that there is no cointegration. The details for the cointegration tests for the sub-samples are reported in Table 6.

\begin{tabular}{|c|c|c|c|c|c|c|}
\hline \multicolumn{7}{|c|}{$\begin{array}{c}\text { Table } 6 \\
\text { Panel Cointegration Tests for the Sub-samples } \\
\end{array}$} \\
\hline \multirow[t]{3}{*}{ Test Statistic } & \multicolumn{3}{|c|}{ Pre-Reforms Sub-Samples } & \multicolumn{3}{|c|}{ Post-Reforms Sub-Samples } \\
\hline & $\begin{array}{c}\text { All } \\
\text { Countries }\end{array}$ & $\begin{array}{l}\text { Early Break } \\
\text { Countries }\end{array}$ & $\begin{array}{c}\text { Late Break } \\
\text { Countries }\end{array}$ & $\begin{array}{c}\text { All } \\
\text { Countries }\end{array}$ & $\begin{array}{l}\text { Early Break } \\
\text { Countries }\end{array}$ & $\begin{array}{l}\text { Late Break } \\
\text { Countries }\end{array}$ \\
\hline & $\begin{array}{l}\text { 1975Q1- } \\
\text { 1985Q4 }\end{array}$ & $\begin{array}{l}\text { 1975Q1- } \\
\text { 1985Q4 }\end{array}$ & $\begin{array}{l}\text { 1975Q1- } \\
\text { 1994Q1 }\end{array}$ & $\begin{array}{l}\text { 1986Q1- } \\
\text { 2008Q4 }\end{array}$ & $\begin{array}{l}\text { 1986Q1- } \\
\text { 2008Q4 }\end{array}$ & $\begin{array}{l}\text { 1994Q2- } \\
\text { 2008Q4 }\end{array}$ \\
\hline $\begin{array}{l}\text { Panel } v \text { - statistic } \\
\text { Eq } 1 . \\
\text { Eq } 3 .\end{array}$ & $\begin{array}{l}1.677 * * \\
-1.767 * *\end{array}$ & $\begin{array}{c}2.079^{*} \\
-3.012^{*}\end{array}$ & $\begin{array}{c}1.899^{* *} \\
1.039\end{array}$ & $\begin{array}{l}-2.459^{*} \\
-1.229\end{array}$ & $\begin{array}{l}2.313^{*} \\
2.060^{*}\end{array}$ & $\begin{array}{l}-5.138^{*} \\
-0.622\end{array}$ \\
\hline $\begin{array}{l}\text { Panel } \sigma \text {-statistic } \\
\text { Eq } 1 . \\
\text { Eq } 3 .\end{array}$ & $\begin{array}{l}-2.916^{*} \\
2.088^{*}\end{array}$ & $\begin{array}{l}2.103^{*} \\
3.416^{*}\end{array}$ & $\begin{array}{l}-1.406 \\
-3.033^{*}\end{array}$ & $\begin{array}{l}-1.685^{* *} \\
-2.394^{*}\end{array}$ & $\begin{array}{c}-4.712^{*} \\
-0.263\end{array}$ & $\begin{array}{l}-3.924^{*} \\
-0.983\end{array}$ \\
\hline $\begin{array}{l}\text { Panel } \rho \rho \text {-statistic } \\
\text { Eq } 1 . \\
\text { Eq } 3 .\end{array}$ & $\begin{array}{l}-4.005^{*} \\
-0.552 \\
\end{array}$ & $\begin{array}{c}-3.778^{*} \\
2.076^{*}\end{array}$ & $\begin{array}{l}-6.190^{*} \\
-3.694 *\end{array}$ & $\begin{array}{c}-1.117 \\
-1.702 * *\end{array}$ & $\begin{array}{c}-1.034 \\
-3.699^{*}\end{array}$ & $\begin{array}{l}-1.115 \\
-4.117^{*}\end{array}$ \\
\hline $\begin{array}{l}\text { Panel ADF-statistic } \\
\text { Eq } 1 . \\
\text { Eq } 3 .\end{array}$ & $\begin{array}{l}3.550^{*} \\
2.189^{*}\end{array}$ & $\begin{array}{l}4.081^{*} \\
2.237^{*}\end{array}$ & $\begin{array}{l}-4.427^{*} \\
-2.413^{*}\end{array}$ & $\begin{array}{l}2.113^{*} \\
2.675^{*}\end{array}$ & $\begin{array}{l}3.817^{*} \\
3.762 *\end{array}$ & $\begin{array}{l}2.034^{*} \\
2.006^{*}\end{array}$ \\
\hline $\begin{array}{l}\text { Group } \sigma \text {-statistic } \\
\text { Eq } 1 . \\
\text { Eq } 3 .\end{array}$ & $\begin{array}{l}-2.423^{*} \\
2.382^{*}\end{array}$ & $\begin{array}{l}-2.059^{*} \\
2.474^{*}\end{array}$ & $\begin{array}{c}-0.531 \\
-1.987^{*}\end{array}$ & $\begin{array}{l}-3.280^{*} \\
-3.352^{*}\end{array}$ & $\begin{array}{l}-3.266^{*} \\
2.748^{*}\end{array}$ & $\begin{array}{c}-5.307^{*} \\
-1.856^{* *}\end{array}$ \\
\hline $\begin{array}{l}\text { Group } \rho \rho \text { - statistic } \\
\text { Eq } 1 . \\
\text { Eq } 3 .\end{array}$ & $\begin{array}{l}-3.046^{*} \\
-1.313\end{array}$ & $\begin{array}{r}-1.305 \\
-0.855\end{array}$ & $\begin{array}{l}-5.981^{*} \\
-2.854^{*}\end{array}$ & $\begin{array}{l}-2.395^{*} \\
-2.221^{*}\end{array}$ & $\begin{array}{l}-2.607 * \\
-0.286\end{array}$ & $\begin{array}{r}-0.755 \\
-1.542 \\
\end{array}$ \\
\hline $\begin{array}{l}\text { Group ADF-statistic } \\
\text { Eq } 1 . \\
\text { Eq } 3 .\end{array}$ & $\begin{array}{l}2.117^{*} \\
1.988^{*}\end{array}$ & $\begin{array}{l}3.775^{*} \\
3.009^{*}\end{array}$ & $\begin{array}{l}-5.189^{*} \\
-4.180^{*}\end{array}$ & $\begin{array}{l}2.283^{*} \\
3.294^{*}\end{array}$ & $\begin{array}{l}2.878^{*} \\
-2.200^{*}\end{array}$ & $\begin{array}{l}2.086^{*} \\
3.861^{*}\end{array}$ \\
\hline $\begin{array}{l}\text { Notes: Australia, Ja } \\
\text { break. Countries tha } \\
\text { distributed as } N(0,1) \\
\text { denotes significance }\end{array}$ & $\begin{array}{l}\text { n, Mexico, } \\
\text { have a late } \\
\text { The critical } \\
\text { respectively }\end{array}$ & $\begin{array}{l}\text { ay, Spain } \\
\text { are Canac } \\
\text { s at } 5 \% \text { a } \\
\% \text { and } 10^{\circ}\end{array}$ & $\begin{array}{l}\text { den, and I } \\
\text { rea, Italy } \\
\text { \% levels a } \\
\text { els. }\end{array}$ & $\begin{array}{l}\text { are the cc } \\
\text { Switzerla } \\
96 \text { and } 1 .\end{array}$ & $\begin{array}{l}\text { ies that ha } \\
\text { he test stat } \\
\text { espectively }\end{array}$ & $\begin{array}{l}\text { n early } \\
\text { cs are } \\
\text { and ** }\end{array}$ \\
\hline
\end{tabular}

In the three sets of sub-samples, the null of no cointegration is rejected by the majority of the cointegration tests at the 5\% level. The only exception is equation (3) in the sub-sample 1994Q2-2008Q4 where panel $v$, panel $\sigma$, group $\sigma$ and group $\rho \rho$ - statistics are insignificant at the 5\% level, however, group $\sigma$ statistic is significant at the $10 \%$ level. 
The more powerful ADF test statistics are significant at the $5 \%$ level in all cases.

Therefore this provides strong evidence that there is cointegration in the three sets of subsample periods.

The cointegrating coefficients for three sets of sub-samples, with alternative break dates, are in Table 7. All the estimated coefficients have the expected signs and are significant at the $5 \%$ level, except for estimates of the coefficient of inflation rate in (3). The estimates of (3) does show that in the post-reforms periods the income elasticity has declined and the rate of interest coefficient has increased in absolute value. Estimates of equation (1) in first set of sub-sample (all countries) show that in post-reforms period the income elasticity has decreased from 0.92 to 0.66 and the coefficient of rate of interest (absolute value) has increased from 0.007 to 0.075 . Fairly similar change in elasticities is observed in the set of sub-samples for countries with the early and late breaks. For countries with early break income elasticity has declined from 0.81 to 0.70 and for the late break countries from 0.71 to 0.62 . The absolute value of the coefficient of the rate of interest has increased from 0.004 to 0.098 and from 0.010 to 0.051 for the early and late break countries respectively. These results imply that in the post-reforms period scale economies have improved although this is more in the 7 countries with an early break. Estimates of equation (3) also support these conclusions although the magnitude of these effects is smaller. On this basis, we can conclude that reforms did improve the expected scale and rate of interest effects. There is also no evidence that a well-defined long run demand for money function does not exist.

\begin{tabular}{|c|c|c|c|c|c|c|c|}
\hline \multicolumn{8}{|c|}{$\begin{array}{c}\text { Table } 7 \\
\text { Pedroni Estimates of the Sub-period Cointegration Coefficients } \\
\text { Dependent Variable: } \log (\mathrm{M})\end{array}$} \\
\hline & \multirow{2}{*}{\begin{tabular}{|l|}
$\begin{array}{l}\text { Sub-sample } \\
\text { periods }\end{array}$ \\
\end{tabular}} & \multicolumn{2}{|c|}{$\ln Y$} & \multicolumn{2}{|c|}{$r$} & \multirow{2}{*}{$\begin{array}{c}\ln E \\
\mathrm{Eq} 3 .\end{array}$} & \multirow{2}{*}{$\begin{array}{c}\pi \\
\mathrm{Eq} 3 .\end{array}$} \\
\hline & & Eq 1. & Eq 3. & Eq 1. & Eq 3. & & \\
\hline \multirow[t]{2}{*}{ All Countries } & $\begin{array}{c}\text { 1975Q1- } \\
1985 \mathrm{Q} 4 \\
\end{array}$ & $\begin{array}{l}0.916 \\
(21.00)^{*}\end{array}$ & $\begin{array}{l}1.011 \\
(14.98)^{*}\end{array}$ & $\begin{array}{l}-0.007 \\
(14.33)^{*}\end{array}$ & $\begin{array}{l}-0.008 \\
(13.33)^{*}\end{array}$ & $\begin{array}{l}-0.166 \\
(2.26)^{*}\end{array}$ & $\begin{array}{l}-0.134 \\
(1.27) \\
\end{array}$ \\
\hline & $\begin{array}{l}\text { 1986Q1- } \\
\text { 2008Q4 }\end{array}$ & $\begin{array}{l}0.656 \\
(23.20)^{*}\end{array}$ & $\begin{array}{l}0.785 \\
(19.72)^{*}\end{array}$ & $\begin{array}{l}-0.075 \\
(11.75)^{*}\end{array}$ & $\begin{array}{l}-0.052 \\
(10.04)^{*}\end{array}$ & $\begin{array}{l}-0.155 \\
(1.48) \\
\end{array}$ & $\begin{array}{l}-0.490 \\
(0.47) \\
\end{array}$ \\
\hline \multirow{2}{*}{$\begin{array}{l}\text { Early Break } \\
\text { Countries }\end{array}$} & $\begin{array}{l}\text { 1975Q1- } \\
\text { 1985Q4 }\end{array}$ & $\begin{array}{l}0.805 \\
(14.28)^{*}\end{array}$ & $\begin{array}{l}0.766 \\
(12.44)^{*}\end{array}$ & $\begin{array}{l}-0.004 \\
(12.19)^{*}\end{array}$ & $\begin{array}{l}-0.007 \\
(10.96) *\end{array}$ & $\begin{array}{l}-0.304 \\
(3.80)^{*}\end{array}$ & $\begin{array}{l}-0.141 \\
(0.24) \\
\end{array}$ \\
\hline & $\begin{array}{l}\text { 1986Q1- } \\
\text { 2008Q4 }\end{array}$ & $\begin{array}{l}0.700 \\
(13.81)^{*}\end{array}$ & $\begin{array}{l}0.611 \\
(10.61)^{*}\end{array}$ & $\begin{array}{l}-0.098 \\
(9.59)^{*}\end{array}$ & $\begin{array}{l}-0.059 \\
(6.52)^{*}\end{array}$ & $\begin{array}{l}-0.085 \\
(1.68)^{* *}\end{array}$ & $\begin{array}{l}-0.965 \\
(1.77)^{* *}\end{array}$ \\
\hline \multirow{2}{*}{$\begin{array}{l}\text { Late Break } \\
\text { Countries }\end{array}$} & $\begin{array}{l}\text { 1975Q1- } \\
\text { 1994Q1 }\end{array}$ & $\begin{array}{l}0.705 \\
(33.72)^{*}\end{array}$ & $\begin{array}{l}0.799 \\
(24.73)^{*}\end{array}$ & $\begin{array}{l}-0.010 \\
(7.41)^{*}\end{array}$ & $\begin{array}{l}-0.009 \\
(6.85)^{*}\end{array}$ & $\begin{array}{l}-0.062 \\
(1.65)^{* *}\end{array}$ & $\begin{array}{l}-0.341 \\
(0.82)\end{array}$ \\
\hline & $\begin{array}{l}\text { 1994Q2- } \\
\text { 2008Q4 }\end{array}$ & $\begin{array}{l}0.616 \\
(15.81)^{*}\end{array}$ & $\begin{array}{l}0.715 \\
(12.04)^{*}\end{array}$ & $\begin{array}{l}-0.051 \\
(6.79)^{*}\end{array}$ & $\begin{array}{l}-0.041 \\
(7.94)^{*}\end{array}$ & $\begin{array}{l}-0.013 \\
(3.10)^{*}\end{array}$ & $\begin{array}{l}-0.276 \\
(1.54) \\
\end{array}$ \\
\hline $\begin{array}{l}\text { Notes: Austral } \\
\text { break. Countri } \\
\text { parentheses an }\end{array}$ & exi & Intce & 17 & $d \mathrm{USA}$ & speet & hat ha & early \\
\hline
\end{tabular}




\section{Conclusion}

This paper has used time series panel data technique of Pedroni (panel FMOLS) to estimate the long run demand for money (M1) for a panel of 11 OECD countries.

Estimates for the entire sample period of 1975Q1 to 2008Q4 showed that income elasticity of demand for money is lower than unity and demand for money responds negatively to variations in the rate of interest. We tested if the financial reforms in these countries had any significant effects. Our sub-sample estimates show that reforms have reduced the income elasticities and the rate of interest semi-elasticity has increased. In the context of money demand, this highlights improved economies of scale, payments technology and the use of money substitutes.

An implication of our results is that financial reforms may have contributed to some instability in the demand for money. But when structural changes are allowed the pre and post reforms sub-sample estimates imply that there is a stable and well defined demand function for money in both sub-samples. The changes in the estimated effects on the parameters seem to be marginally higher in the countries that have implemented the reforms early. Another implication of our findings is that the central banks in these countries should reconsider their choice of using the interest rate as their monetary policy instrument because according to Poole money supply should be used as the monetary policy instrument when the demand for money is stable. Recent shift towards quantitative targets by the central banks in Europe may be based on the realisation that the demand for money may have been stable now because many major effects of reforms may have already taken place. 


\section{Data Appendix}

$Y=$ Real GDP at factor cost. Data are from IFS-2009.

$R=$ The average of 1-3 years savings deposit rate. Data are from IFS-2009.

$M=$ Real narrow money supply. Data are from IFS-2009.

$E=$ Real effective exchange rate. Data are from IFS-2009.

$\pi=$ Rate of inflation calculated with GDP deflator. Data are from IFS-2009.

Note:

All real variables are their nominal values deflated with the GDP deflator. 


\section{REFERENCES}

Bahmani-Oskooee, M. and Gelan, A. (2009) 'How stable is the demand for money in African countries,' Journal of Economic Studies, 36, 216-235.

Bahmani-Oskooee, M. and Rehman, H.(2005) 'Stability of the money demand function in Asian developing countries,' Applied Economics, 37, 773-792.

Baltagi, B. H. (2005) Econometric Analysis of Panel Data, Chester, UK: John Wiley, $3^{\text {rd }}$ edition.

Ball, L. (2001) 'Another look at long-run money demand,' Journal of Monetary Economics, 47, 31-44.

Breitung, J. (2000) 'The local power of some unit root tests for panel data, in Baltagi, B. (ed.), Advances in Econometrics, 15. Nonstationary panels, panel cointegration, and dynamic panels,' JAI Press, Amsterdam, pp. 161-178.

(2006) 'A parametric approach to the estimation of cointegration vectors in panel data,' Econometric Reviews, 24, 151-173.

Breuer, J.B. and Lippert, A.F. (1996) 'Breaks in money demand,' Southern Economic Journal, 63, 496-506.

Cagan, P. (1956) 'The monetary dynamics of hyperinflation.' In: Friedman M (Ed), Studies in the quantity theory of money, University of Chicago Press: Chicago.

Caporale, G.M. and Gil-Alana, L.A. (2005) 'Fractional cointegration and aggregate money demand functions,' The Manchester School, 73, 737-753.

Carrera, C. (2008) 'Long-run money demand in Latin-American countries: nonestationary panel data approach,' available at http://www.williams.edu/cde/. 
Dreger, C., Reimers, H-E. and Roffia, B. (2007) 'Long-run money demand in the new EU member states with exchange rate effects,' Eastern European Economics, 45, 75-94.

Duca, J.V. and VanHoose, D.D. (2004) 'Recent developments in understanding the demand for money,' Journal of Economics and Business, 56, 247-272.

Elbadawi, I.A. and Schmidt-Hebbel, K. (2007) 'The demand for money around the end of civil wars,' available at http://siteresources.worldbank.org.

Fidrmuc, J. (2009) 'Money demand and disinflation in selected CEECs during the accession to the EU,' Applied Economics, 41, 1259-1267.

Friedman, M. and Kuttner, K.N. (1992) 'Money, income, prices, and interest rates, 'American Economic Review, 82, 472-92.

Gacia-Hiernaux, A. and Cerno, L. (2006) 'Empirical evidence for a money demand function" a panel data analysis of 27 countries in 1988-98,' Applied Econometrics and International Development, 6, 1-15.

Hadri, K. (2000) 'Testing for stationarity in heterogeneous panel data,' Econometric Journal, 3, 148-161.

Hamori, S. (2008) 'Empirical analysis of the money demand function in Sub-Saharan Africa,' Economics Bulletin, 15, 1-15.

Hamori, N. and Hamori, S. (2008) 'Demand for money in the Euro Area,' Economic Systems, 32, 274-284.

Harb, N. (2004) 'Money demand function: a heterogeneous panel application,' Applied Economics Letters, 11, 551-555.

Haug, A.A. (1999) 'Money demand functions: data span and tests,' available at http://www.econ.canterbury.ac.nz/research/working_papers.shtml. 
Im, K.S., Pesaran, M.H and Shin, Y. (2003) 'Testing for unit roots in heterogeneous panels,' Journal of Econometrics, 115, 53-74.

Kao, C. (1999) 'Spurious regression and residual-based tests for cointegration in panel data,' Journal of Econometrics, 90, 1-44.

Lee, C-C. and Chang, C.P. (2006) 'Multivariate panel cointegration models and money demand function,' available at www.finance.nsysu.edu.tw.

Levin, A., Lin, C.F. and Chu, C. (2002) 'Unit root tests in panel data: asymptotic and finite sample properties,' Journal of Econometrics, 108, 1-24.

Maki, D. and Kitasaka, S. (2006) 'The equilibrium relationship among money, income, prices, and interest rates: evidence from a threshold cointegration test,' Applied Economics, 38, 1585-1592.

Mancini-Griffoli, T. and Pauwels, L.L. (2006) 'Is there a Euro effect on trade? An application of end-of-sample structural break tests for panel data,' HEI Working Paper No 04, Economics Section, The Graduate Institute of International Studies.

Mark, N.C. and Sul, D. (2003) 'Cointegration vector estimation by panel DOLS and longrun money demand,' Oxford Bulletin of Economics and Statistics, 65, 665-680.

McPhail, K. (1991) 'The long-run demand for money, Canada savings bonds and treasury bills in Canada,' available at http://www.esri.go.jp/en/archive/dis/discussion-e.html.

Nagayasu, J. (2003) 'A re-examination of the Japanese money demand function and structural shifts,' Journal of Policy Modeling, 25, 359-375.

Nielsen, H. (2004) 'UK money demand 1873-2001: a cointegrated VAR analysis with additive data corrections,' Cliometrica, 1, 45-61.

Orden, D. and Fisher, L.A. (1993) 'Financial deregulation and the dynamics of 
money, prices, and output in New Zealand and Australia,' Journal of Money, Credit, and Banking, 25, 273-92.

Oxley, L.T. (1983) 'Functional and structural breaks in the UK demand for money function: 1963-1979,' Journal of Economic Studies, 10, 22-41.

Papadopoulos, A.P. and Zis, G. (1997) 'The demand for money in Greece: further empirical results and policy implications,' The Manchester School, 65, 71-89.

Pedroni, P. (2000) 'Fully modified OLS for the heterogeneous cointegrated panels, in Baltagi, B. (ed.) Advances in econometrics, 15, Nonstationary panels, panel cointegration and dynamic panels, JAI Press, Amsterdam, pp. 93-130.

(2004) 'Panel cointegration: asymptotic and finite sample properties of pooled time series tests with an application to the PPP hypothesis,' Econometric Theory, 3, 579-625.

Pesaran, M. H. and Breitung, J. (2005) 'Unit roots and cointegration in panels,' Discussion Paper Series 1: Economic Studies No 42/2005, Deutsche Bundesbank, Frankfurt, Germany.

Poole, W. (1970) 'The optimal choice of monetary policy instruments in a simple macro model,' Quarterly Journal of Economics, 84, 197-216.

Rao, B.B. and Kumar, S. (2009a) 'Is the US demand for money unstable?' available at http://mpra.ub.uni-muenchen.de/15715/.

(2009b) 'A panel data approach to the demand for money and the effects of financial reforms in the Asian countries,' Economic Modelling, 26, 10121017.

Rao, B.B., Tamazian, A. and Singh, P. (2009) 'Demand for money in the Asian countries: a systems GMM panel data approach and structural breaks,' available at http://ideas.repec.org/p/pra/mprapa/15030.html. 
Setzer, R. and Wolff, G.B. (2009) 'Money demand in the euro area: new insights from disaggregated data,' available at http://ec.europa.eu/economy_finance/publications.

Sriram, S. S. (2001) ‘A survey of recent empirical money demand studies,' IMF Staff Papers, 47, 334-365.

(1999) 'Survey of literature on demand for money: theoretical and empirical work with special reference to error-correction models,' IMF Working Paper 7WP/99/64 (Washington DC: International Monetary Fund).

Sumner, M. (2009) 'Demand for money in Thailand,' Applied Economics, 41, 1269-1276.

Valadkhani, A. (2008) 'Long and short run determinants of the demand for money in the Asian-Pacific countries: an empirical panel investigation,' Annals of Economics and Finance, 9, 77-90.

Valadkhani, A. and Alauddin, M. (2003) 'Demand for M2 in developing countries: an empirical panel investigation,' School of Economics and Finance Discussion Paper No. 149 (Queensland: Queensland University of Technology).

Vega, J. L. (1995) 'Is the ALP long-run demand function stable? Banco de Espana, Documento de Trabajo, No. 9422.

(1998) 'Money demand and stability: evidence from Spain,' Empirical Economics, 23, 387-400.

Westerlund, J. (2006) 'Testing for panel cointegration with multiple structural breaks,' Oxford Bulletin of Economics and Statistics, 68, 101-132.

Yu, H. and Gan, P-T. (2009) 'An empirical analysis of the money demand function in ASEAN-5,' International Research Journal of Finance and Economics, 33, 168-177. 